\title{
INTERNATIONAL COOPERATION COMPETENCES AND THEIR ASSESSMENT CRITERIA WITHIN THE PROCESS OF EDUCATING EXTERNAL RELATIONS SPECIALISTS
}

\author{
Anete Mežote, Vija Dišlere \\ Latvia University of Agriculture, Jelgava, Latvia \\ E-mail: anetemezote@inbox.lv, vija.dislere@llu.lv
}

\begin{abstract}
To successfully develop certain competences in students, it is necessary to define the competences, as well as to set assessment criteria to be used in the process of developing, assessing and further developing of the competences. Due to the developing nature of international cooperation among organizations, the criteria for assessing international cooperation competences must comprise and assess all components of the particular competences that are necessary in typical job situations in the present time in the field where the prospective specialists (the current students) are planning to work, as well as all components of competences that individuals should possess in accordance with the constructivist learning theory, thus fostering a learning environment where students motivate themselves and construct their knowledge accordingly. The article defines international cooperation competences of external relations specialists, as well as sets, describes and justifies their assessment criteria, taking into account the prospective job environments of these specialists along with progressive learning theories. The set assessment criteria can also be used to assess international cooperation competences of students of other study fields where foreign language or communication courses are acquired. Apart from defining international cooperation competences and their assessment criteria, the study results present the comparison of the assessment of competences by means of using the set criteria and grades in simulations and in the standard written final examination, thus justifying the need for the set criteria to assess the most important components of the mentioned competences properly on the basis of practical competence demonstration and testing.
\end{abstract}

Key words: international cooperation, competence, assessment criteria, education.

\section{Introduction}

As international cooperation is a field of activity that is important for any specialist working in a developing organization, international cooperation competences, i. e., competences necessary for cooperation with foreign partners, play a major role in ensuring both successful performance of the specialist and successful operation of the organization. If the cooperation is of a national level, adequately developed social competence and field knowledge may be sufficient for achieving the needed results. However, if the cooperation is of an international level, cross-cultural communication competence and other skills needed to cooperate internationally are required, as cultural differences tend to make the process of cooperating internationally more difficult. Due to this reason, special attention needs to be paid to developing international cooperation competencies in students that need to be ready for cooperating internationally after the graduation. To make sure the specialists are competent and can cope with work duties successfully, international cooperation competences shall be developed properly during studies, which is not so at the moment (Mezote, 2012). Therefore, the competences must be studied and defined and the most important specific components of international cooperation competences 
Anete MEŽOTE, Vija DIŠLERE. International Cooperation Competences and Their Assessment Criteria within the Process of Educating External Relations Specialists

PROBLEMS

OF EDUCATION

IN THE $21^{\text {st }}$ CENTURY

Volume 60, 2014

126

must be identified, taking into account the current working environment, work requirements, future perspectives, as well as progressive learning theories, etc.

After the acquisition of study courses developing international cooperation competence during the study process, the acquired competences shall be tested to find out if and to what extent the prospective specialists are ready for work. To ensure an appropriate process of assessing the mentioned competences, as well as to ensure an appropriate process of the competence development and the result (the developed competences), assessment criteria need to be set according to the work duties of the prospective specialists along with their descriptors in order to help educators identify the presence of certain competences and their components and to find out which components of international cooperation competences need to be further developed in relation to the tested students or more developed in general in relation to the future students.

The need for defining international cooperation competences and setting appropriate criteria for their assessment is justified by the research problem: the fact that students during their studies do not acquire appropriate practical skills needed for successful cooperation with foreign partners (Mezote, 2012) and before graduation mostly only their theoretical knowledge is assessed (in this case the students of the study programme External Relations of Organizations are analysed), resulting in their fair ability to cooperate successfully internationally.

Keeping the progressive learning theories and especially the constructivist approach in mind, educators shall foster the process of learning rather than teach the content (Marton, Saljo, 1976; Marton, Hounsell, Entwistle, 1997; Prosser, Trigwell, 1999; Biggs, Tang, 1999). Thus the students must be motivated and oriented towards a purposeful and meaningful learning process. The learning outcomes of the study course Cross-cultural communication (in which international cooperation competences of the prospective external relations specialists, i. e., External Relations Unit Managers, are developed at the Latvia University of Agriculture) are described as knowledge about the theories of culture, different cultures, essence of cross-cultural communication and means of communication; skills to apply the acquired theories, means and knowledge, to overcome cultural barriers and culture shock, to ensure cooperation with representatives of different cultures and work in a multicultural environment; competence comprising awareness of, understanding, accepting and respecting cultural differences, as well as abilities for evaluating, reflecting and adapting personal performance (Ārējo sakaru..., 2012). By linking the learning outcomes with appropriate assessment criteria, greater coherence in curriculum design can be achieved, thus, achieving constructive alignment (Biggs, Tang, 1999). Along with setting appropriate assessment criteria, it is necessary to develop teaching strategies that could help the students achieve the study results and meet the requirements of the criteria set according to their prospective job environments. To ensure constructive alignment, it is necessary to define what and to what extent the students must learn, as well as to assist the students in applying the acquired knowledge and skills (Biggs, Tang, 1999). That, as mentioned before, can be achieved by setting appropriate criteria in order to assess the learning outcomes properly. The criteria for assessing competences need to be explicit, available, open to interrogation and shared (Brown, Glasser, 1999). Time to time, the criteria must be reconsidered and adapted according to the current job requirements. In relation to developing international cooperation competences and assessing them in cross-cultural communication situations, as well as in many other situations, competences can be split into two groups: threshold and differentiating competences (Sanghi, 2007). Threshold competence assessment reveals if the individual can or cannot implement certain duties, whereas differentiating competence assessment reveals that either the individual cannot implement the duties or is an average (effective), or a superior performer (Sanghi, 2007). As the threshold competences can be assessed simply by observing whether the individual can or cannot implement a certain duty, the criteria set and described further in the article serve for assessing the differentiating international cooperation competences in cross-cultural communication situations. It is also important to note that threshold competences can be acquired mostly by applying any learning approach, while differentiating competences 
develop effectively in most situations only if the deep learning approach is applied, i. e., when the student concentrates on the main goal of learning and understands the importance of and

PROBLEMS

OF EDUCATION

IN THE $211^{\text {st }}$ CENTURY

Volume 60,2014

need for the knowledge, skills, competences, etc. to be acquired (Ramsden, 2003; Biggs, Tang, 1999). Due to this reason, the deep learning approach must be encouraged according to the principles of the constructivist approach in order to develop competences of students successfully to a level that makes it possible for them to perform successfully in their prospective jobs.

\section{Methodology of Research}

\section{General Background of Research}

Methods of theoretical description and analysis of curriculum theories, as well as constructivist and other pedagogical theories have been used to discuss the concept of cooperative social competence (Izdonaite-Medziuniene, Medziunas, 2008), constructivist learning theories (Marton, Saljo, 1976; Marton, Hounsell, Entwistle, 1997; Prosser, Trigwell, 1999; Biggs, Tang, 1999) along with the five pillars of education for sustainable development (Education for..., 2010), as well as to define international cooperation competences of external relations specialists and set, describe and justify the criteria for assessing these competences in students who acquire and need to possess them in order to succeed in their prospective job. Methods of practical sector-related analysis have been used to interpret the research results in the speciality (sector) and provide conclusions, but the set criteria as such were used to assess the level of international cooperation competence of students of the study programme External Relations of Organizations (Latvia University of Agriculture).

\section{Sample of Research}

Sixteen 4th year students who acquired the study course Cross-cultural Communication, delivered by the author, by means of simulations (study programme External Relations of Organizations, Latvia University of Agriculture, Faculty of Economics and Social Development; the total number of students in the group learning by mans of simulations). The research is limited to simulating content needed for external relations specialists, therefore the conclusions apply to the extent of competence of external relations specialists. The research is also limited to Latvian students as content adapted to them is taught and simulated.

\section{Instrument and Procedures}

The data were obtained from testing the performance of the mentioned students by means of simulations (by the set criteria and by grades) and of analysing the grades in final examinations in the mentioned study course (study year 2012/2013) in order to test the usefulness of the set criteria. The instruments used were: context descriptions, the set criteria with the descriptors, the simulations grades with a pre-set point system; multiple-choice examinations with a pre-set point system.

\section{Data Analysis}

The grades (for simulations and for final written multiple-choice examinations) were compared by means of Chi-Square Test (SPSS Statistics 17.0) to prove the fact that the grades in simulations are lower, as the ability to demonstrate competences practically is assessed. 
Anete MEŽOTE, Vija DIŠLERE. International Cooperation Competences and Their Assessment Criteria within the Process of Educating External Relations Specialists

OF EDUCATION

IN THE $21^{\text {st }}$ CENTURY

Volume 60, 2014

128

\section{Results of Research}

The international cooperation competence structure (Figure 1) assists in defining the international cooperation competence components, as well as setting the appropriate assessment criteria.

\begin{tabular}{|l|l|l|}
\hline $\begin{array}{l}\text { Professional } \\
\text { competence } \\
\text { of external } \\
\text { relations } \\
\text { specialists }\end{array}$ & $\begin{array}{l}\text { International cooperation } \\
\text { competence of external } \\
\text { relations specialists }\end{array}$ & $\begin{array}{l}\text { Cooperative social } \\
\text { competence }\end{array}$ \\
\hline & $\begin{array}{l}\text { Cross-cultural } \\
\text { competence }\end{array}$ & Social competence \\
\hline
\end{tabular}

\section{Figure 1: Structure of international cooperation competences of external rela- tions specialists.}

Similarly, the international cooperation competence assessment criteria and their descriptors (Table 1) are derived from the definitions of competences and competence components related to the appropriate kinds of competence (professional and social in this case) (Figure 1), as well as international cooperation situations.

Table 1. Criteria (and descriptors) for assessing international cooperation competences of the prospective Latvian external relations specialists.

\begin{tabular}{|c|c|c|c|c|c|}
\hline $\begin{array}{l}\text { Descrip- } \\
\text { torl } \\
\text { level of } \\
\text { compe- } \\
\text { tence }\end{array}$ & $\begin{array}{l}\text { Communicative } \\
\text { competence }\end{array}$ & $\begin{array}{l}\text { Cooperation } \\
\text { competence }\end{array}$ & $\begin{array}{l}\text { Cultural com- } \\
\text { petence }\end{array}$ & $\begin{array}{l}\text { Informative } \\
\text { competence } \\
\text { and tactics }\end{array}$ & $\begin{array}{l}\text { Self-directed } \\
\text { learning compe- } \\
\text { tence }\end{array}$ \\
\hline $\begin{array}{l}\text { Student is } \\
\text { unable to } \\
\text { demon- } \\
\text { strate com- } \\
\text { petence }\end{array}$ & $\begin{array}{l}\text { Unable to com- } \\
\text { municate (commu- } \\
\text { nication barriers or } \\
\text { problems): unable to } \\
\text { cooperate }\end{array}$ & $\begin{array}{l}\text { Unable to } \\
\text { work in team } \\
\text { and control } \\
\text { and organize } \\
\text { work: unable to } \\
\text { cooperate }\end{array}$ & $\begin{array}{l}\text { Not aware of } \\
\text { and/or cannot } \\
\text { accept cultural } \\
\text { differences: un- } \\
\text { able to cooper- } \\
\text { ate }\end{array}$ & $\begin{array}{l}\text { Unable to ana- } \\
\text { lyse problems } \\
\text { and choose } \\
\text { appropriate } \\
\text { tactics: unable to } \\
\text { cooperate }\end{array}$ & $\begin{array}{l}\text { Not aware of the } \\
\text { importance of } \\
\text { cooperation com- } \\
\text { petences, no inter- } \\
\text { est in developing } \\
\text { them: unable to } \\
\text { cooperate }\end{array}$ \\
\hline $\begin{array}{l}\text { Student } \\
\text { is an } \\
\text { effective } \\
\text { performer } \\
\text { (average } \\
\text { level) }\end{array}$ & $\begin{array}{l}\text { Does not face } \\
\text { significant problems } \\
\text { or overcomes } \\
\text { them, does not } \\
\text { significantly hamper } \\
\text { communication: able } \\
\text { to cooperate; no } \\
\text { additional achieve- } \\
\text { ments }\end{array}$ & $\begin{array}{l}\text { Able to work in } \\
\text { team, control, } \\
\text { organize, no } \\
\text { cooperation } \\
\text { problems or } \\
\text { overcoming } \\
\text { them: } \\
\text { able to } \\
\text { cooperate; } \\
\text { no additional } \\
\text { achievements }\end{array}$ & $\begin{array}{l}\text { Aware of and } \\
\text { can accept } \\
\text { differences, } \\
\text { no mistakes in } \\
\text { relation to ana- } \\
\text { lysing partner's } \\
\text { reactions: able } \\
\text { to cooperate; } \\
\text { no additional } \\
\text { achievements }\end{array}$ & $\begin{array}{l}\text { Able to analyse } \\
\text { problems and } \\
\text { choose tactics, } \\
\text { facing no rejec- } \\
\text { tions: able to } \\
\text { cooperate; } \\
\text { no additional } \\
\text { achievements }\end{array}$ & $\begin{array}{l}\text { Aware of the } \\
\text { importance of } \\
\text { competences, } \\
\text { interest in devel- } \\
\text { oping, showing } \\
\text { signs contradic- } \\
\text { tory to successful } \\
\text { development: able } \\
\text { to cooperate; no } \\
\text { additional achieve- } \\
\text { ments }\end{array}$ \\
\hline $\begin{array}{l}\text { Student is } \\
\text { a superior } \\
\text { performer }\end{array}$ & $\begin{array}{l}\text { Does not face } \\
\text { barriers/ problems, } \\
\text { appreciated by } \\
\text { partner: able to co- } \\
\text { operate and ensure } \\
\text { additional achieve- } \\
\text { ments }\end{array}$ & $\begin{array}{l}\text { Able to work in } \\
\text { team, organ- } \\
\text { ize, facing no } \\
\text { problems, } \\
\text { appreciated: } \\
\text { able to cooper- } \\
\text { ate, additional } \\
\text { achievements }\end{array}$ & $\begin{array}{l}\text { Can accept } \\
\text { differences, } \\
\text { no mistakes, } \\
\text { appreciated by } \\
\text { partner: able to } \\
\text { cooperate; addi- } \\
\text { tional achieve- } \\
\text { ments }\end{array}$ & $\begin{array}{l}\text { Able to analyse } \\
\text { problems, } \\
\text { choose tactics, } \\
\text { no rejections: } \\
\text { able to cooper- } \\
\text { ate, additional } \\
\text { achievements }\end{array}$ & $\begin{array}{l}\text { Aware of the im- } \\
\text { portance of com- } \\
\text { petences, interest } \\
\text { in developing, } \\
\text { successful plan: } \\
\text { able to cooperate, } \\
\text { additional achieve- } \\
\text { ments }\end{array}$ \\
\hline
\end{tabular}


Table 2. Comparison of student international cooperation competence assessment by means of using the set criteria and grades in simulations and in the final examination.

\begin{tabular}{lll}
\hline $\begin{array}{l}\text { Assessment of simulations by the set criteria: } \\
\text { ability to perform cooperation }\end{array}$ & $\begin{array}{l}\text { Cooperation simulation } \\
\text { grades (1-10) }\end{array}$ & $\begin{array}{l}\text { Final examination grades } \\
(1-10)\end{array}$ \\
\hline Unable & 4 & 5 \\
\hline Unable & 4 & 6 \\
\hline Unable & 5 & 6 \\
\hline Able & 6 & 7 \\
\hline Able & 7 & 7 \\
\hline Able & 7 & 8 \\
\hline Able & 8 & 9 \\
\hline Able & 8 & 9 \\
\hline Able & 8 & 9 \\
\hline Superior performer & 9 & 9 \\
\hline Superior performer & 9 & 10 \\
\hline Superior performer & 9 & 10 \\
\hline Superior performer & 10 & 10 \\
\hline Superior performer & 10 & 10 \\
\hline Superior performer & 10 & 10 \\
\hline Superior performer & 10 & 10 \\
\hline & & 9 \\
\hline
\end{tabular}

Table 3. Chi-Square test of the assessment of student grades in simulations and in the final examination.

\begin{tabular}{llll}
\hline Chi-Square Tests & & & \\
\hline Pearson Chi-Square & Value & df & Asymp. Sig. (2-sided) \\
\hline Likelihood Ratio & $51,556^{\mathrm{a}}$ & 30 & 0.009 \\
\hline Linear-by-Linear Association & 41,222 & 30 & 0.083 \\
\hline $\mathrm{N}$ of Valid Cases & 14,066 & 1 & 0.000 \\
\hline a. 42 cells $(100,0 \%)$ have expected count less than 5. The minimum expected count is $0,06$. \\
\hline
\end{tabular}

The usefulness of simulations as such is justified, as the simulation grades, as well as assessments by the criteria (see Table 2 and Table 3 ) are lower for all students and significantly different (Asymp. Sig. (2-tailed) is 0.009 (Chi-Square Test, SPSS Statistics 17.0) than final examination grades, testifying to the fact that in a written examination it has been impossible to assess international cooperation competence (which needs to be practically demonstrated and assessed in line with cooperation results) properly. 
Anete MEŽOTE, Vija DIŠLERE. International Cooperation Competences and Their Assessment Criteria within the Process of Educating External Relations Specialists

\section{PROBLEMS \\ OF EDUCATION \\ IN THE $21^{\text {st }}$ CENTURY \\ Volume 60, 2014 \\ 130 \\ Discussion}

There are several overlapping kinds of competence: meta-competence, key competence, social competence, professional competence and self-competence (Briede, Pēks, 2011), and all of these competences build the personality supplementing each other. However, to a large extent international cooperation competences fall into the group of social competences. To state the components which the international cooperation competences of external relations specialists comprise, studies in the field of external relations and external relations specialists professional competence, as well as cooperative social competence have been taken into account, as international cooperation competences of external relations specialists to a large extent overlap with the professional competence of external relations specialists defined as the ability to achieve the profession-related results by applying knowledge and skills manifested through attitudes (Turu eva, 2010), as well as cooperative social competence characterized by management skills, interpersonal skills and team work through educational processes and creativity (IzdonaiteMedziuniene, Medziunas, 2008). According to the descriptions of differentiating competences by Sanghi (2007), as well as to previous study results of the author (Mezote, 2012) in relation to the current job environments in the field of external relations in Latvia, to research in the field of professional competence of external relations specialists (Turu eva, 2010) and to cooperative social competence (Izdonaite-Medziuniene, Medziunas, 2008) definitions, international cooperation competences of external relations specialists are defined, by the author, as comprising communicative competence, cooperation competence, culture competence, informative competence along with the ability to choose appropriate communication and cooperation tactics, self-management and learning (self-directed learning) competence, as well as the awareness of the importance of international cooperation competences. These competences influence the student's performance in cooperation situations, as well as according to these competences the performance can be assessed as ineffective (unable to cooperate), average/effective (able to cooperate) or superior. Therefore, international cooperation (especially differentiating, rather than easily demonstrated threshold) competences can be assessed by means of assessing separate sets of components which the international cooperation competences comprise: communicative competence; cooperation competence (considering that the prospective cooperation is mutually beneficial); culture competence; informative competence and choice of communication and cooperation tactics; self-management and learning competence along with the understanding of the importance of international cooperation competences. According to the definition, these competences can be considered as overlapping with several other competences (see Figure 1). It should also be noted that successful international cooperation challenges all kinds of competence in general, since it involves communication on an international level and motivated lifelong learning in line with the constructivist approach.

The definition of international cooperation competences of external relations specialists, as well as simulations organized by the author within the study course Cross-cultural Communication makes it possible to set criteria for assessing the mentioned competences (see Table 1). The descriptors of the criteria are based on the observations of the author during the simulations organized for the students within the course, corresponding to the descriptions of Sanghi (2007) in relation to the defined study outcomes of the mentioned course. The set criteria assist in assessing the components of international cooperation competences that need to be practically demonstrated (and developed), rather than written multiple-choice questions to be answered in an examination after acquiring theoretical knowledge. Similarly, the descriptors of the criteria ensure the possibility for the educators to assess also those other components of competences that are challenged within an international cooperation situation typical of the current work environments and correspond to the current job requirements, as well as those which individuals need to possess along with progressive learning theories. However, to ensure proper assessment, the set criteria are best to be used in situations identical to the current job situations and environments, selecting proper cooperation partner cultures, work situations, etc. 
The need for the international cooperation competence assessment criteria is justified by the fact that the simulation criteria levels for cooperation competence component as such to a large extent correspond to the cooperation simulation grades (also assessed in relation to the ability to demonstrate all of the needed competence components) of the students of the study programme External Relations of Organizations (Faculty of Economics and Social Development, Latvia University of Agriculture), study course Cross-cultural Communication (see Table 2 ), at the same time providing the opportunity to measure the international cooperation competences according to the competence levels described by Sanghi (2007).

As Table 2 reveals, the cooperation competence component criteria descriptor "Unable" corresponds to grades 4-5; "Able" corresponds to grades 6-8 (effective performer, described by Sanghi (2007) as average level), and "Superior performer" corresponds to grades 9-10. Therefore, it becomes clear that it is possible that a student with an average standard grade level (grade 5) of competence is assessed by the criteria as "Unable" (to cooperate successfully) due to the failure to demonstrate a complete ability to achieve all major and minor cooperation results. At the same time, apart from the standard viewpoint that only grade 10 could reflect superior performance of a student, it becomes clear that the set criteria describe a student with the grade 9 as "Superior performer", meaning that the person has achieved all major and minor cooperation results, but has demonstrated certain lack of knowledge or skills, etc. It can be concluded that the criteria (set in accordance with the international cooperation competence definition derived from the five pillars of education, constructivist approach and currently typical job duties and situations in the field of external relations) make it possible to assess the cooperation results, rather than certain knowledge or other competence components, which makes them fully appropriate for assessing international cooperation competences of prospective external relations specialists for working in developing organizations. The assessment by the set criteria also reveals the motivation of students to develop the competences further. Since the simulation grades, as well as assessments by the criteria (Table 2) are lower for all students and significantly different than final examination grades, it is proved that in a written examination it has been impossible to assess international cooperation competence (its practical implications) properly. Such results justify the need to reconsider the process of assessing student competences at the end of any study course in order to make sure that the students have developed and finally possess the competence components which are really necessary for them as for the prospective field specialists. In relation to the study course Cross-cultural Communication, it can be concluded that the set criteria for assessing international cooperation competences of the prospective external relations specialists ensure development and assessment of international cooperation competences which these field specialists will need in their future jobs, if the criteria are used to assess the competences demonstrated by the students during and at the end of the study course by means of simulating the current typical job situations in the field. It should be noted that the constructivist learning approach may foster the development of international cooperation competences (e.g., by means of raising interest, motivating, etc), however the set criteria may be used in any case, as well as for assessing any other similar competences. The main advantage of the set criteria is the possibility to make sure that a final assessment of students is made on the basis of assessing the competences that actually should have been practically developed in the study course and will be needed in future, rather than assessing certain knowledge in a written form of examination. For this reason, it would be useful to consider changing the form of the final examination (e.g., in this case it is suggested to change the form of final examination of the study course Cross-cultural Communication from written to oral/ kinaesthetic/simulations) in order to avoid situations when graduates find themselves unable to act in work situations. 
Anete MEŽOTE, Vija DIŠLERE. International Cooperation Competences and Their Assessment Criteria within the Process of Educating External Relations Specialists

\section{PROBLEMS \\ OF EDUCATION \\ IN THE $21^{\text {st }}$ CENTURY \\ Volume 60, 2014 \\ 132 Conclusions}

International cooperation competences to be developed in Latvian students comprise communicative competence, cooperation competence, culture competence, informative competence along with the ability to choose appropriate communication and cooperation tactics, self-management and learning competence, as well as the awareness of the importance of international cooperation competences.

Assessment of differentiating international cooperation competences of the prospective Latvian external relations specialists must comprise assessment of communicative, cooperation, culture, informative and self-management competence in 3 levels: ineffective, effective and superior performer.

Assessment of international cooperation competences without the need for the students to demonstrate the competences practically (in simulations) tends to indicate to a higher level of student learning results, as mostly only theoretical knowledge is assessed, rather than a practical competence, which may lead to an incorrectly assessed student learning results before graduation, as well as to a situation when the prospective external relations specialists find themselves not able to cooperate internationally well enough in future.

The international cooperation competence assessment criteria provide the possibility to assess the level of practically demonstrated competences and the achieved international cooperation results in order to make sure that the needed competences are developed in students and successful cooperation can be ensured after graduation.

\section{References}

Ārējo sakaru struktūrvienības vadītāja profesijas standarts. (2012). Profesionālās izglītības un nodarbinātības trīspusējās sadarbības apakšpadome. Retrieved 12/01/2014, from http://www. llu.lv/getfile.php?id=48062

Biggs, J. B., Tang, C. (1999). Teaching for quality learning at university. Buckingham: Society for Research into Higher Education.

Briede, B., Pēks, L. (2011). Ekologiskā pieeja izglītībā. Jelgava: Latvijas Lauksaimniecības universitāte, Izglìtības un mājsaimniecības institūts, 2011. (CD ROM).

Brown, S., Glasser, A. (1999). Assessment Matters in Higher Education: choosing and using diverse approaches. Buckingham: Society for Research into Higher Education.

Education for Sustainable Development Lens: A Policy and Practice Review Tool Education for Sustainable Development in Action. (2010). UNESCO Education Sector. Retrieved 11/01/2014, from http://unesdoc.unesco.org/images/0019/001908/190898e.pdf

Izdonaite-Medziuniene, I., Medziunas, R. (2008). Cooperative Social Competence Development: Aspect of Tourism Managers in Lithuanian Higher Education. In: Proceedings of IX International Scientific Converence "Darba tirgus sociālie un ekonomiskie izaicinājumi”. Rīga: BA Turība, 2008. Retrieved 11/02/2014, from http://www.turiba.lv/darba_tirgus_2008/

Marton, F., Hounsell, D., Entwistle, N. (1997). The experience of learning. Edinburgh: Scottish Academic Press.

Marton, F., Saljo, R. (1976). On qualitative differences in learning - 1: outcome and process. British Journal of Educational Psychology, 46, 4-11.

Mezote, A. (2012). Competences Currently Necessary for External Relations Specialists. Ed. Pol., Man. and Qual., 40, 122-128.

Prosser, M., Trigwell, K. (1999). Understanding Learning And Teaching: The Experience in Higher Education. Buckingham: Open University Press.

Ramsden, P. (2003). Learning to Teach in Higher Education. London: Routladge Falmer.

Sanghi, S. (2007). The Handbook of Competency Mapping: Understanding, Designing and Implementing Competency Models in Organizations. New Delhi: Sage Publications.

Turu eva, L. (2010). Ārējo sakaru struktūrvienības vadītāja profesionālā kompetence un tās veidošanās studiju procesā (Doctoral dissertations). Rīga: Latvijas Universitāte. 
Anete MEŽOTE, Vija DIŠLERE. International Cooperation Competences and Their Assessment Criteria within the Process of Educating External Relations Specialists

$$
\begin{array}{l|l}
\text { Advised by Laima Railiene, SMC “Scientia Educologica”, Lithuania } & \begin{array}{l}
\text { PROBLEMS } \\
\text { OF EDUCATION } \\
\text { IN THE 215tCENTRY } \\
\text { Volume 60, 2014 }
\end{array} \\
\cline { 2 - 2 }
\end{array}
$$

Received: May 09, 2014

Accepted: July 02, 2014

\begin{tabular}{|ll} 
Anete Mežote & Mg.ed., Lecturer, Latvia University of Agriculture, Lielā iela 2, Jelgava, LV- \\
& 3002, Latvia. \\
& E-mail: anetemezote@inbox.Iv \\
\hline Vija Dišlere & $\begin{array}{l}\text { Dr.paed., Associate Professor, Latvia University of Agriculture, Lielā iela 2, } \\
\text { Jelgava, LV-3002, Latvia. } \\
\text { E-mail: Vija.Dislere@llu.lv }\end{array}$
\end{tabular}

